\title{
Multinational tax avoidance: An application of controlled foreign companies and royalty payments in South African legislation
}

\author{
Nicholas Brown \\ Shaun Parsons \\ Riley Carpenter \\ College of Accounting, University of Cape Town, South Africa
}

\section{Key Words}

Tax avoidance, avoidance schemes, multinationals, South Africa, controlled foreign company, royalty payment

\begin{abstract}
This paper seeks to determine whether South African tax legislation would limit the effectiveness of tax avoidance schemes used by multinational enterprises to avoid their tax liabilities. The paper reviews two commonly used multinational tax avoidance schemes, namely, disregarding controlled foreign companies ('check box' regulations) and royalty payments. Using a doctrinal research methodology, the paper considers the application of these schemes within the context of South African legislation. The findings indicate that the effectiveness of the schemes is somewhat curtailed. However, the South African tax base remains at risk, and efforts to combat base erosion are still necessary.
\end{abstract}

\section{Introduction}

Multinational tax avoidance refers to the ability of a firm to reduce its liabilities by using avoidance methods that legally shift profits to lower tax jurisdictions or by avoiding to pay tax altogether (Gravelle, 2009). Multinational tax avoidance has been brought to the broader public's attention following extensive criticism in recent years of the tax practices of a number of high-profile multinationals. Multinational enterprises generate taxable incomes that are significant sources of revenue for their respective tax jurisdictions and, as such, tax authorities realise the importance of collecting their fair share of tax revenue. Tax authorities face the challenge of instituting legislation to eliminate loopholes without hindering global competitiveness. Some countries, particularly those with smaller economies, have sought to attract foreign investment through, amongst other methods, low corporate tax rates. For example, Microsoft negotiated with the Puerto Rican tax authorities in 2012 to be taxed at a rate of $2 \%$, which was lower than the nation's 20\% corporate tax rate (United States Senate Committee on Homeland Security and Governmental Affairs, 2012). These negotiations have spurred criticism from other tax authorities such as Her Majesty's Revenue and Customs in the United Kingdom (UK). Furthermore, the avoidance methods used by multinationals have led tax authorities to question the level of corporate social responsibility displayed, suggesting that manipulating the legislation is unethical (Davis Tax Committee, 2016b). The criticism made by tax authorities has damaged the reputation of multinationals, resulting in some of them choosing to pay tax in order to pose as good corporate citizens to please customers (Macalister, 2013). Starbucks announced in 2013 that it would pay tax in the UK despite its persistent reported losses while Amazon decided to record a portion of its sales in the UK where it will be consequently taxed, having previously re-routed those sales to Luxembourg - a lower tax jurisdiction (Bowers, 2015).

Controlled foreign companies are foreign entities of multinational group structures. In some circumstances, these entities can avoid paying tax in the parent company's jurisdiction, thereby reducing the group's tax liabilities. Multinationals also potentially have the opportunity of licensing intellectual property in return for royalty payments, thereby shifting profits (and tax liabilities) to possibly lower tax jurisdictions.

South Africa has a substantial budget deficit. One way to improve this is to collect more tax, and more specifically, corporate tax. Judge Dennis Davis of the Davis Tax Committee has stated that increasing the collection of corporate taxes is imperative if South Africa wishes to facilitate economic 
growth and reduce its budget deficit (Davis Tax Committee, 2016a). However, as a developing country, South Africa has a relatively low fiscal capacity (Besley \& Persson, 2013). Research indicates that profit shifting is rife in low-income economies (Kar \& Spanjers, 2015; Ndikumana, 2016) and this is exacerbated by multinationals practising tax avoidance in less developed countries (Johannesen, Tørsløv, \& Wier, 2020). Consequently, tax base erosion, profit-shifting and international tax competition have a potentially greater effect on developing economies (Crivelli, De Mooij, \& Keen, 2015). It has been found that it is possible for multinationals in the oil and gas sector to avoid South African tax (Lu \& Carpenter, 2020).

Subsequent to the multinational tax avoidance schemes being identified, they have garnered much attention, including consideration in the recent Base Erosion and Profit-Sharing (BEPS) project of the Organisation for Economic Co-operation and Development (OECD) and the G20 (OECD, 2013; 2015). It has been recommended that South Africa continue to follow the OECD and developed countries' actions with respect to tax base erosion (Wilson, Parsons, \& Carpenter, 2016).

Using a doctrinal research methodology, this paper establishes whether South African legislation curbs tax avoidance schemes such as controlled foreign companies and royalty payments to minimise the tax liabilities of multinationals.

The paper begins by considering the South African tax context. It then reviews avoidance methods in the literature and explains how such schemes are allegedly being practised by multinationals such as Google and Starbucks. The research methodology is then described in greater detail. Thereafter, South African tax legislation is explained and applied to the avoidance methods to determine its ability to limit the effectiveness of these methods. Finally, the paper concludes by discussing the research limitations and providing recommendations for further research.

\section{Literature review \\ Residence and source}

In South Africa, income tax is administered through the Income Tax Act (No. 58 of 1962) (hereafter referred to as the Income Tax Act). In the Income Tax Act, the section 1 definition of 'gross income' legislates that a person is taxed on a residence basis. This means that South African residents must be taxed on their worldwide income irrespective of the source of the income. A juristic person, such as a company, is deemed to be a South African resident if it is incorporated, established, or formed in South Africa, or if its place of effective management is in South Africa (section 1 of the Income Tax Act's definition of 'resident').

In contrast, non-residents are taxed on a source basis (as per the 'gross income' definition in section 1 of the Income Tax Act). This means that non-residents are taxed only on income which is of a South African source. The interpretation of the source basis has differed since its introduction and thus court cases have established the way in which the source of income is to be determined. In Commissioner for Inland Revenue v Lever Brothers \& Unilever Ltd (1946 AD 441)(14 SATC 1), the court held that the originating cause of the income must first be established. Following from this, the location of the originating cause must be determined in order to identify the source of the income. However, even with these principles, source can still be difficult to determine. It is possible for more than one originating cause to exist and as such, the dominant cause must be determined.

Section 9 of the Income Tax Act provides specific source rules for certain types of income such as the sale of goods and royalty income. However, where the Income Tax Act does not explicitly provide for a type of income, the source is often where the business is carried on or where the capital is employed.

Based on these rules, a company must pay tax to the South African Revenue Service (SARS) if its income is subject to these rules. Where the application of these rules results in income being subjected to tax in two jurisdictions, the taxpayer may obtain relief - either through a foreign tax credit granted in terms of domestic legislation or in terms of the provisions of a double tax agreement. As such, a multinational may avoid tax by diverting profits in a manner that - although in accordance with the Income Tax Act - results in it paying tax to a different jurisdiction. Multinationals exploit such loopholes, which allow them to pay tax in a jurisdiction that levies a lower tax rate on corporate profits. Multinationals by their very nature perform transactions between different companies within the multinational corporation that are situated in different tax jurisdictions. However, the substance of these 
transactions must be questioned to determine whether they have genuine economic substance, or whether they are conducted primarily for the purpose of minimising tax liabilities.

There are numerous tax avoidance schemes that are used by multinational enterprises. This paper focuses on multinational enterprises incorporated in the United States (US) or whose parent companies are residents of the US. These multinationals also have foreign operations creating a large presence in Europe. Consequently, this paper discusses principles from the tax systems of the US and some European countries as well as tax guidelines issued by the OECD. While the primary objective is not to identify loopholes in the tax systems in which the multinational enterprises operate, the paper does provide insights into foreign tax laws and explains how the schemes exploit such loopholes. This background is then referred to when considering the application of the schemes within the South African legal context. In some instances, quantitative data is provided to highlight the substantial impact of these schemes on the multinationals' tax liabilities and the tax benefits that they derive.

\section{Tax avoidance using controlled foreign companies and royalty payments}

Multinational enterprises by definition have foreign entities within their group structures. The profits earned by these foreign entities are sometimes required to be included in the taxable income of the parent company. However, the introduction of 'check box' regulations has allowed multinational enterprises to disregard the taxable income of these foreign entities. In this way, the enterprises examined in this study avoid having to pay US corporate tax on the foreign entities' profits. For a multinational enterprise to exercise this option, it would need to ensure that the foreign entity could be classified as an 'eligible entity'. This term refers to a business entity that is not treated as a corporation. Once a foreign entity is deemed an eligible entity, it may be classified as a 'disregarded entity' if it has a single owner who does not have limited liability. The 'check box' regulations were introduced to simplify the process of classifying entities. However, they have inadvertently provided scope for multinational enterprises to substantially reduce their tax liabilities - which multinationals have duly taken advantage of (United States Senate Committee on Homeland Security and Governmental Affairs, 2012). Thus, many multinational enterprises have structured their operations in such a way as to exploit these regulations. 'Check box' regulations defer offshore profits from being taxed in the US because the repatriation of profits is deemed a dividend; they are therefore only taxed upon repatriation. However, multinational enterprises are under no obligation to repatriate profits and very often choose not to do so.

Royalty payments are often used in conjunction with the 'check box' regulations to shift profits to lower tax jurisdictions (Gravelle, 2015). Many of the multinationals that have successfully implemented tax avoidance schemes are technology companies which license their intellectual property in return for royalty payments. An example of the 'check box' regulations used in conjunction with royalty payments is the 'Double Irish Dutch Sandwich' - allegedly used by Google (Fuest, Spengel, Finke, Heckemeyer, \& Nusser, 2013). Google received approval over its proposed scheme from the US' Internal Revenue Service in 2006, thereby ensuring that the scheme fell within the definition of tax avoidance and not tax evasion. The scheme is explained below.

Google's parent company in the US licensed its intellectual property to a subsidiary in Ireland Google Ireland Holdings. Google Ireland Holdings owns a company, also situated in Ireland, named Google Ireland Limited. However, Bermuda is recognised as Google Ireland Holdings' place of effective management (Fuest et al., 2013). According to US tax law, Google Ireland Limited and Google Ireland Holdings are treated as one Irish company (Fuest et al., 2013). As a result, US tax laws regarding controlled foreign companies that would require the inclusion of the Irish company's net income in the parent company's taxable income, are circumvented through 'check box' regulations. This is because Google's parent company is the sole owner of the Irish subsidiaries and does not have limited liability. Therefore, it meets the requirements to disregard the foreign entities, and thus to legally exclude the net income of the foreign entities from its own taxable income. At the same time, Irish tax laws deem Google Ireland Holdings to be a resident of Bermuda (Fuest et al., 2013). Consequently, the taxable income of Google Ireland Holdings is taxed in Bermuda at a rate of 0\% (Hennigan, 2013; International Monetary Fund, 2018).

Google Ireland Limited sells advertising, earning 88\% of Google's foreign sales in 2009 (Drucker, 2010). However, the company reported taxable income of a substantially smaller amount, as evidenced by 
its pre-tax income in 2008 being less than 1\% of its sales (Drucker, 2010). Google Ireland Limited achieved this by paying a royalty to Google Ireland Holdings for the use of its intellectual property. For example, in 2008 Google Ireland Limited paid Google Ireland Holdings a royalty of \$5.4 billion (Drucker, 2010). By 2012 , the royalty amounted to $\$ 8.6$ billion, representing an increase of 59\% (Smith, 2013). The royalty paid by Google Ireland Limited is not paid directly to Google Ireland Holdings. Instead, a company is created in the Netherlands, and it is this company that Google Ireland Limited pays. Paying the Dutch company results in no withholding taxes on the royalty payment since the amount is deemed a transfer between countries within the European Union (Drucker, 2010). Any taxable income of Google Ireland Limited that remains after the royalty payment to the Dutch company is taxed at $12.5 \%$, which is substantially lower than the $35 \%$ tax rate levied on corporations in the US. The Dutch company then makes a royalty payment to Google Ireland Holdings.

This 'Double Irish Dutch Sandwich' relied upon Ireland taxing Google Ireland Holdings based upon its place of effective management. This was one of the reasons for the change in 2015, when Ireland altered its definition of tax residence to include entities both effectively managed or incorporated in Ireland. However, existing structures were grandfathered up until 2020 (International Monetary Fund, 2018).

Starbucks' European subsidiaries made royalty payments amounting to $6 \%$ of turnover to a company in the Netherlands, which headquarters its European operations (royalty payments of $4.7 \%$ were made after Starbucks' UK subsidiary appeared in front of Her Majesty's Revenue and Customs) (Bergin, 2012b; UK House of Commons Public Accounts Committee, 2013). In 2011, Starbucks' UK subsidiary made a royalty payment of $£ 26$ million which significantly contributed towards a $£ 33$ million loss that year, resulting in no tax charge in that country (Bergin, 2013). In comparison, other multinationals such as McDonalds - the largest restaurant chain around the globe - made royalty payments of between $4 \%$ and $5 \%$ of turnover (Bergin, 2012a).

According to tax legislation in the UK, these royalty payments can be deducted if Starbucks is able to show that the royalty payment is an arm's length transaction. One way in which Starbucks can justify this is to show the importance of the intellectual property (for which the royalty is paid) to the profitability of the UK subsidiary's operations. Starbucks has maintained that its royalty payments were at arm's length despite continued losses reported by its UK subsidiary (Bergin, 2012b).

In summary, high-profile multinational enterprises have used the controlled foreign companies' 'check box' regulations, allowing the parent company to disregard its foreign subsidiaries. The parent company was thus given the opportunity of making a choice insofar as it was able to determine whether its foreign subsidiaries were eligible entities.

\section{Methodology}

Using doctrinal research methodology, this paper seeks to determine whether South African tax legislation would limit the effectiveness of schemes such as controlled foreign companies and royalty payments in avoiding the tax liabilities of multinational enterprises.

For the purposes of applying the South African legislation to the avoidance methods, hypothetical resident parent Company A seeks to exclude the taxable income of foreign Companies B and C. Operations are located in foreign subsidiary $\mathrm{C}$ rather than in resident Company A. A foreign subsidiary would thus make a royalty payment to another subsidiary to ensure the profits were transferred to a lower tax jurisdiction to avoid the tax liability in South Africa.

The relevant South African tax legislation is first explained before being applied to the avoidance scheme. In some instances, the South African legislation lacks sections that specifically govern the relevant transactions and schemes. However, the Commissioner for SARS considers guidance provided by the OECD - which has already contemplated foreign tax codes - before determining the substance of the transaction or scheme with respect to tax avoidance. Therefore, the guidelines of the referenced tax codes are applied to the schemes as this reflects what the Commissioner would consider. There are also facts and circumstances that the Commissioner may consider upon making an inquiry into the tax practices of multinational enterprises. While these facts and circumstances are not incorporated into the legislation, they are nonetheless relevant to the Commissioner's decision and are therefore also considered. 


\section{Application to South African legislation \\ Controlled foreign companies}

According to section 1 of the Income Tax Act, a company is a resident if it is incorporated or effectively managed within South Africa. If neither of these requirements are fulfilled, then a company is deemed a non-resident company.

Section 9D of the Income Tax Act governs the treatment of controlled foreign companies. This section was introduced because it was anticipated that multinational enterprises would artificially transfer profits offshore to tax havens where South African tax would be unlikely to impede international competitiveness (National Treasury, 2002). The legislation states that a controlled foreign company is any foreign company in which one or more residents holds directly or indirectly more than $50 \%$ of the participation rights or has the ability to exercise more than $50 \%$ of the voting rights. Furthermore, if a resident company - together with connected persons (resident or non-resident) - controls a foreign company in accordance with the aforementioned requirements, and if, in turn that foreign company has the ability to exercise more than $50 \%$ of the voting rights in another foreign company, then the latter foreign company is also deemed a controlled foreign company. The net income of these controlled foreign companies is included in the taxable income of the parent company to the extent of the parent company's effective interest in each controlled foreign company. Certain exclusions in section 9D preclude the parent company from having to include the net income of the controlled foreign company into its taxable income. If the parent company, together with connected persons, holds less than $10 \%$ of the participation rights in the controlled foreign company, then the net income inclusion amounts to nil. In addition, if the foreign tax levied on the controlled foreign company is equal to or greater than $67.5 \%$ of the South African tax, calculated on the controlled foreign company's taxable income, then the net income inclusion also amounts to nil. Lastly, if the controlled foreign company is a foreign business establishment of the resident parent company, the net income is not included in the taxable income of the parent. The deductions against the income of a controlled foreign company are limited to the said income. Therefore, the inclusion of a controlled foreign company's net income cannot reduce the taxable income of the parent company. If the deductions exceed the net income, the excess deductions are carried forward to the next year of assessment.

Company A may seek to reduce its exposure to tax in South Africa by restructuring in such a way that it transfers its operations into Company C, a non-resident company in a low-tax jurisdiction. Company $\mathrm{C}$ then services the customers of the group. To the extent that those customers are located in South Africa, such income may continue to be from a South African source in terms of South African tax legislation, depending on the nature of the business. However, if Company $C$ is able to invoke the provisions of a double tax agreement between South Africa and its country of residence, assuming that the agreement conforms to the OECD Model Tax Convention, it is likely that such profits will be liable to tax only in Company C's country of residence in terms of the article 7 Business Profits. However, this is only if Company $C$ has a permanent establishment in South Africa (OECD, 2019). As economies shift from brick-and-mortar operations towards digital services, it becomes increasingly likely that this can be achieved.

The profits of Company C may, however, be at risk of taxation in South Africa under section 9D of the Income Tax Act. A significant component of the success of a 'Double Irish Dutch Sandwich' scheme is that Company A is able to 'check the box', resulting in Company B's and C's taxable income not being consolidated into Company A. Because of the absence of an elective provision in the South African legislation to disregard foreign subsidiaries, Company A would need to look to other provisions for exclusion. Company A holds $100 \%$ of the participation rights in Companies B and C. Therefore, it cannot apply the exclusion for holding together with its connected persons less than $10 \%$ of the participation rights in Companies B and C. Ireland's corporate tax rate is $12.5 \%$. This is significantly lower than the $18.9 \%$ (calculated as $67.5 \%$ of $28 \%$ ) effective tax rate required for the exclusion to apply. As such, Company A cannot apply the $75 \%$ rule either.

The foreign business establishment exclusion from section 9D of the Income Tax Act was applied in order to facilitate international competitiveness. However, this exclusion can only apply if it does not threaten the South African tax base (National Treasury, 2002). Accordingly, the three factors that a 
business establishment must possess are permanence, economic substance, and a reason for operating in a foreign country other than for tax purposes. With reference to the last factor, Companies B and C must have a bona fide non-tax business reason for operating in a low-tax jurisdiction and not in South Africa (National Treasury, 2002). This paper outlines Google's tax advantage from having subsidiaries in Ireland. In order to convince SARS that its subsidiaries in a low-tax jurisdiction are foreign business establishments, Company $\mathrm{C}$ will have to demonstrate that its operations are indeed a foreign business establishment. If it manages to do so, its profits will not be subject to tax in South Africa through the inclusion of its net income in Company A's taxable income in terms of section 9D. However, schemes such as the one described above often revolve around the relocation of intellectual property - an intangible asset - rather than the relocation of business operations. An advantage of intangible assets is that they are easily transferrable across international borders. Assuming Company A operates via the internet, it can reach its customers around the world. Therefore, Company A could reach its global customer base from South Africa without necessarily requiring subsidiaries in foreign countries to expand its international competitiveness. It would therefore be more difficult to prove that Company $\mathrm{C}$ is operating a foreign business establishment. If SARS were to deem its reasoning for operating abroad inadequate, the foreign business establishment exclusion would not apply.

Therefore, Company A would not meet any of the requirements to exclude the net income of its foreign subsidiaries. The net income would be included in the taxable income of the parent company and subject to a corporate tax rate of $28 \%$ under section 9D. The absence of a 'check box' provision in the South African income tax legislation and the provisions of section 9D prevent a multinational enterprise from earning offshore profits through its subsidiaries without it being taxed in South Africa. This is on the condition that the subsidiary is a controlled foreign company (i.e., it is a non-resident but does not have a proper foreign business establishment).

\section{Royalties}

If Company $\mathrm{C}$ is required, by the nature of its business, to maintain a permanent establishment in South Africa (or indeed if it is a South African tax resident), it will remain liable for tax in South Africa. Company $\mathrm{C}$ may therefore seek to reduce its South African tax exposure by paying a royalty to fellow non-resident subsidiary, Company B.

Section 9D (9) of the Income Tax Act states that a controlled foreign company must exclude any amount in the form of royalties from its net income if those royalties are received from another controlled foreign company and if both controlled foreign companies form part of the same multinational enterprise. Consequently, the controlled foreign company paying the royalties is disallowed from deducting the royalty payments when determining its net income. A 'Double Irish Dutch Sandwich' typically involves the payment of a royalty between two controlled foreign companies - in this case Companies B and C. However, the application of section 9D of the Income Tax Act treats the transaction as though it did not occur. As such, section 9D not only ensures that the multinational enterprise's controlled foreign companies are taxed but also ensures that the profits are attributed to the controlled foreign companies through which they were earned - even though it makes no difference from a South African tax point of view (the net income is included in Company A's taxable income). The reversing of royalties ensures there is no double-counting of the section 9D effect.

While Company $\mathrm{C}$ is not prevented from deducting its royalty payment in full, it must look to sections $49 \mathrm{~A}$ to $49 \mathrm{H}$ of the Income Tax Act to determine whether it is obliged to withhold a royalty withholding tax of $15 \%$ upon the payment of a royalty to a non-resident - the Dutch subsidiary - hereafter referred to as Company B. The only exemption available to companies (other than headquarter companies) is if the non-resident company carried on business at any time during the 12-month period preceding the date on which the royalty was paid, or if the business was carried on through a permanent establishment of the non-resident in South Africa. Company B is not tax-resident in South Africa whereas Company $C$ is not a permanent establishment of Company B since they are separate legal entities (OECD, 2019). As such, the exemption does not apply. Company $C$ would be obliged to withhold $15 \%$ royalty withholdings tax, which is effectively levied on Company B.

The royalty paid to Company B is from a South African source. However, if it were subject to the withholding tax on royalties in South Africa, it would be exempt from any further income tax 
consequences in South Africa. Furthermore, Company B may be entitled to invoke the provisions of a double tax treaty between South Africa and its country of residence, if such a treaty were to exist. Articles on the taxation of royalties assign exclusive taxing rights to the country of residence if they follow the OECD Model Tax Convention. Company B would therefore not be subject to any income tax consequences in South Africa (OECD, 2019).

For the purposes of applying the following section of the South African legislation, it is assumed that the intellectual property of the multinational enterprise was created in South Africa (by Company A), and that the multinational enterprise subsequently transferred that intellectual property out of South Africa (to Company B). The multinational enterprise would need to consider whether section 23I would prevent it from reducing its tax liability. Section 23I prohibits the deduction of royalties paid to a nonresident (and to tax-exempt entities) for the use of what is referred to in the Income Tax Act as 'tainted intellectual property'. Although there are numerous provisions, only one is required to be met for intellectual property to be deemed 'tainted'. Essentially, the provisions apply when (i) the intellectual property is, or was, the property of either a taxable person or the end user and (ii) the intellectual property is used within South Africa. A taxable person, as defined under section 23I, refers to a person who is a resident (with certain exclusions that are not relevant for the purposes of this paper). The section defines an end user as a taxable person or a person with a permanent establishment in South Africa who uses the intellectual property to derive income. If the intellectual property is not tainted, section 23I will not apply. Furthermore, if the person to which the royalty is paid is taxed in South Africa upon receipt of the royalty, section 23I does not apply. In the event that section 23I does not apply, the royalty payment is deductible in its entirety. If the royalty is subject to the withholding tax of $15 \%$ in South Africa, the deduction of that royalty expenditure is limited to one half of the expenditure incurred.

Company $\mathrm{C}$ is the end user given that it uses the intellectual property to derive income other than by means of granting its use to another person. However, the intellectual property does not belong to Company C. It is the property of Company B. Company B is not a taxable person of South Africa, as defined, given that it is not a resident. However, the intellectual property was acquired from Company A. Therefore, the intellectual property is tainted and section 23I of the Income Tax Act will apply, providing an effective remedy to the intended tax avoidance.

\section{General anti-avoidance}

Sections 80A through to 80L of the Income Tax Act contain general anti-avoidance legislation. These provisions identify avoidance arrangements that lack commercial substance, are not at arm's length or where the sole or main purpose is to derive a tax benefit. The onus falls on the taxpayer to prove that the sole or main purpose of the arrangement is not to avoid tax. In establishing the purpose of the arrangement, its substance is assessed, not its form. This is essential in determining the intention of the parties. Furthermore, SARS must show that there is an element of abnormality embodied by the arrangement. To show abnormality, it must be proved that there is no bona fide reason for the arrangement, except the tax benefit. Should the Commissioner for SARS determine that an impermissible tax avoidance arrangement has occurred, he is able to levy tax by re-characterising the terms of the arrangement (for example, treating separate connected persons as one person). Sections $80 \mathrm{~A}$ to $80 \mathrm{~L}$ are principle-based, and not prescriptive. Consequently, they provide limited guidance to companies on the way in which they should structure arrangements.

\section{Conclusion}

This paper sought to determine whether South African tax legislation would limit the effectiveness of two tax avoidance schemes used by multinational enterprises to minimise their tax liabilities. It discussed how multinational enterprises have allegedly structured their operations in such a manner that they shift their profits to lower tax jurisdictions and minimise their tax liabilities. The two avoidance schemes included disregarding controlled foreign companies ('check box' regulations) and royalty payments. Application was demonstrated by showing how multinational enterprises such as Google are alleged to have implemented the schemes within the broader context of tax avoidance. The paper considered the application of these schemes within the South African legal context. To this end, the paper 
assumed that the parent company was a South African tax resident - a central assumption in the avoidance scheme.

The paper found mixed results. In some circumstances the Income Tax Act limited the effectiveness with which multinational schemes could avoid tax in South Africa. If a multinational company were able to relocate its business operations from South Africa to a foreign subsidiary and to continue servicing its customers without setting up a permanent establishment in South Africa, it may be able to reduce its South African tax liability. However, controlled foreign companies' net incomes would need to be included in the taxable incomes of their parent companies if the foreign business exclusion does not apply. South Africa's withholdings tax on royalties from a South African source resulted in a lower rate of taxation than the standard company rate. Intellectual property was transferred offshore while continuing to be used in South Africa. The deduction of such royalty expenditure is prohibited either in part or in full. This prohibition limits the opportunity to artificially reduce income taxes in South Africa through the payment of royalties to non-residents.

Although South African income tax legislation contains measures to prevent tax avoidance of the nature allegedly practised by multinational companies in the two schemes considered, the South African tax base remains at risk. As modern businesses increasingly shift towards e-commerce, the permanent establishment test may be an inappropriate means of protecting the country's tax base. Furthermore, information asymmetry and deliberate attempts to obscure the true nature of such schemes may frustrate the application of the South African anti-avoidance provisions discussed in this paper. To this end, initiatives to combat base erosion that gained traction following the exposure of these schemes - most notably the OECD's BEPS Project (OECD, 2013, 2015) and consideration of a digital presence test - could meaningfully contribute to the defence of the South African tax base.

\section{Limitations and areas for future research}

The paper is subject to quantitative limitations in determining the extent to which South African legislation curbs the ability of multinationals to minimise their tax liabilities. Access to quantitative data would allow further research into this topic to evaluate the extent to which the South African legislation limits the effectiveness of such avoidance schemes.

\section{References}

Bergin, T. (2012a). Special Report: How Starbucks avoids UK taxes. Retrieved November 7, 2020, from https://www.reuters.com/article/idUSBRE89E0EX20121015

Bergin, T. (2012b). Special Report: Starbucks's European tax bill disappears down $\$ 100$ million hole. Retrieved November 7 , 2020, from https://www.reuters.com/article/idUSBRE8A00DP20121101

Bergin, T. (2013). Starbucks reports UK loss, pays no tax for 2012. Retrieved November 7, 2020, from https://www.reuters.com/article/us-starbucks-tax-britain-idUSBRE95R0YE20130628

Besley, T., \& Persson, T. (2013). Chapter 2 - Taxation and Development. In A. J. Auerbach, R. Chetty, M. Feldstein, \& E. Saez (Eds.), Handbook of Public Economics (Vol. 5, pp. 51-110). Elsevier. https:// doi.org/https://doi.org/10.1016/B978-0-444-53759-1.00002-9

Bowers, S. (2015). Amazon to begin paying corporation tax on UK retail sales. Retrieved November 7, 2020, from https://www.theguardian.com/technology/2015/may/23/amazon-to-begin-paying-corporation-tax-on-ukretail-sales

Commissioner for Inland Revenue v Lever Brothers \& Unilever Ltd (1946 AD 441)(14 SATC 1) (1946).

Crivelli, E., De Mooij, R. A., \& Keen, M. M. (2015). Base erosion, profit shifting and developing countries (IMF Working Paper WP/15/118). Washington.

Davis Tax Committee. (2016a). Macro analysis of the tax system and inclusive growth in South Africa. Retrieved from https://www.taxcom.org.za/docs/20160421 DTC Macro Analysis Final Report - Full Report.pdf

Davis Tax Committee. (2016b). Second interim report on base erosion and profit shifting (BEPS) in South Africa: Introduction. Retrieved from https://www.taxcom.org.za/docs/New_Folder3/2 BEPS Final Report - Introductory Report.pdf

Drucker, J. (2010). Google 2.4\% Rate Shows How \$60 Billion Is Lost to Tax Loopholes. Retrieved November 7, 2020, from https://www.bloomberg.com/news/articles/2010-10-21/google-2-4-rate-shows-how-60-billion-u-s-revenuelost-to-tax-loopholes

Fuest, C., Spengel, C., Finke, K., Heckemeyer, J., \& Nusser, H. (2013). Profit Shifting and 'Aggressive' Tax Planning by Multinational Firms: Issues and Options for Reform (ZEW Discussion Paper No. 13-044). Retrieved from https://dx.doi.org/10.2139/ssrn.2303676 
Gravelle, J. (2009). Tax Havens: International Tax Avoidance and Evasion. National Tax Journal, 62(4), 727-753. https://doi.org/dx.doi.org/10.17310/ntj.2009.4.07

Gravelle, J. (2015). Tax Havens: International Tax Avoidance and Evasion. CRS Report. Washington. Retrieved from https://fas.org/sgp/crs/misc/R40623.pdf

Hennigan, M. (2013). Google's Irish-Dutch sandwich grew to €8.8bn in 2012. Retrieved November 7, 2020, from http://www.finfacts.ie/irishfinancenews/article_1026677.shtml

International Monetary Fund. (2018). Ireland: Selected issues. Country report no. 18/195. Washington. Retrieved from https://www.imf.org/en/Publications/CR/Issues/2018/06/28/Ireland-Selected-Issues-46027

Johannesen, N., Tørsløv, T., \& Wier, L. (2020). Are less developed countries more exposed to multinational tax avoidance? Method and evidence from micro-data. The World Bank Economic Review, 34(3), 790-809. https://doi.org/https://doi.org/10.1093/wber/lhz002

Kar, D., \& Spanjers, J. (2015). Illicit Financial Flows from Developing Countries: 2004-2013. Washington. Retrieved from https:// secureservercdn.net/45.40.149.159/34n.8bd.myftpupload.com/wp-content/uploads/2015/12/IFFUpdate_2015-Final-1.pdf

Lu, S., \& Carpenter, R. (2020) 'Tax Avoidance by Multinational Corporations in the Oil and Gas Sector in South Africa: An Exploratory Study', in 2020 Southern African Accounting Association National Teaching and Learning and Regional Conference Proceedings in association with the Meditari Accountancy Research Conference. 2 October. Cape Town. ISBN: 978-0-620-90856-6

Macalister, T. (2013). Starbucks pays corporation tax in UK for first time in five years. Retrieved November 7, 2020, from https://www.theguardian.com/business/2013/jun/23/starbucks-pays-corporation-tax

National Treasury. (2002). Detailed Explanation to Section 9D of the Income Tax Act. Pretoria.

Ndikumana, L. (2016). Trade misinvoicing in primary commodities in developing countries: The cases of Chile, Côte d'Ivoire, Nigeria, South Africa and Zambia. Geneva: UNCTAD.

Organisation for Economic Co-operation and Deverlopment (OECD). (2013). Action Plan on Base Erosion and Profit Shifting. Paris: OECD Publishing. https://doi.org/http://dx.doi.org/10.1787/9789264202719-en

Organisation for Economic Co-operation and Deverlopment (OECD). (2015). Limiting Base Erosion Involving Interest Deductions and Other Financial Payments, Action 4 - 2015 Final Report. Paris: OECD Publishing. https://doi.org/https://doi.org/10.1787/9789264241176-en

Organisation for Economic Co-operation and Deverlopment (OECD). (2019). Model Tax Convention on Income and on Capital 2017 (Full Version). Paris: OECD Publishing. https://doi.org/10.1787/g2g972ee-en

Smith, L. (2013). €8.8bn of royalty payments channelled through Bermuda by Google. Retrieved November 7, 2020, from http:/ / www.independent.co.uk/life-style/gadgets-and-tech/88bn-of-royalty-payments-channelled-throughbermuda-by-google-8874287.html

UK House of Commons Public Accounts Committee. (2013). Tax Avoidance-Google. London: House of Commons. Retrieved from https://publications.parliament.uk/pa/cm201314/cmselect/cmpubacc/112/112.pdf

United States Senate Committee on Homeland Security and Governmental Affairs. (2012). Offshore Profit Shifting and the U.S. Tax Code. Washington.

Wilson, A., Parsons, S., \& Carpenter, R. (2016) 'The effect of electronic commerce on the erosion of tax bases Developing appropriate taxation laws in South Africa', in 2016 Southern African Accounting Association (SAAA) National Teaching and Learning and Regional Conference Proceedings. November. Cape Town. ISBN: 978-0-62074761-5 